\title{
The Role of Cell Wall-Degrading Enzymes in the Development of Anthracnose Disease Caused by Colletotrichumtruncatum in the Chilli
}

\author{
Remli N.A.M. ${ }^{1}$, Shah U.K.M ${ }^{1,2 *}$, Ariff A.B ${ }^{1,2}$, MohdTermizi Yusof ${ }^{3}$, Lim H.S $^{4}$ \\ ${ }^{1}$ Department of Bioprocess Technology, Malaysia \\ ${ }^{2}$ Bioprocess and Biomanufacturing Research Center, Malaysia \\ ${ }^{3}$ Department of Microbiology, Faculty Biotechnology and Biomolecular Sciences, Universiti Putra Malaysia, \\ ${ }^{4}$ Agrobiodiversity and Environmental Research Centre, Malaysian Agricultural Research and Development Institure, 43400 \\ Serdang, Selangor, Malaysia. \\ *Corresponding Author - Assoc. Prof. Dr. UmiKalsom Md Shah \\ Associate Professor in Bioprocess Technology, Department of Bioprocess Technology, Faculty Biotechnology and \\ Biomolecular Sciences, Universiti Putra Malaysia, Serdang, Selangor, Malaysia.
}

\begin{abstract}
The ability of Colletotrichumtruncatum CP2 in producing pectinolytic and cellulolytic enzymes was evaluated by shake flask fermentations. The results of enzymatic activity experiment indicated that $P G$ was the first cell wall-degrading enzymes detected and the activities obtained were higher $(0.24 \pm 0.10 \mathrm{U} / \mathrm{mL})$ than other enzymes, which appeared later and in lower amount. After the cell wall was degraded by the action of PG, further degradation of the cell wall was affected by pectin methylesterases, pectin lyase, pectate lyase and cellulases. The disparity in enzymatic activity at different intervals may suggest their specific role for pathogenesis at proper timings.
\end{abstract}

Keywords-Chilli anthracnose; Colletotrichumtruncatum, cell wall-degrading enzymes, pectinolytic, cellulolytic.

\section{INTRODUCTION}

Chilli (Capsicum апnиит L.) belongs to the Solanaceae family is a profitable crop worldwide as it is not exclusively used as a spice in numerous cooking styles but also found to have numerous therapeutic properties. Chillies are commercially grown in tropical and sub-tropical countries like India, China, Japan, United States of America and African countries (Saxena et al., 2016). Nonetheless, numerous limitations have significantly decreased chilli production worldwide. Plant disease caused by mainly fungi is the major constrain in chilli production worldwide as it can affect both tropical and subtropical region and even in temperate region.

The secretion of cell wall-degrading enzymes by fungal pathogen is an important factor that contributes to the pathogenicity of fungal pathogens during interaction with its host. These cell wall-degrading enzymes enable the fungal pathogens to penetrate into the cell wall more easily due to the decomposition of the cell wall polyshaccharides. Subsequently, the fungal pathogens will acquire the carbon from the decomposed plant tissues. Several studies have addressed the cell wall-degrading enzymes secretion by fungal pathogens and its specific relation with pathogenicity (Niture, 2008).

Recently, most research has been intensified on the pectinolytic enzymes secreted by fungal pathogens. The virulence of many pathogens has been suggested to be dependent on the level of pectinolytic enzymes produced during infection (Rogers et al., 2000).However, the specific role of these enzymes in pathogenesis of fungal pathogen in chilli is still unknown. Till date, there are no published reports on pectinolytic enzymes activities related to pathogenicity of $C$. truncatumin chilli anthracnose. The aim of this study was to determine the production of cell wall-degrading enzymes by $C$. truncatum CP2 in submerged fermentation as a preliminary step to establish the role of these enzymes in the C. truncatum $\mathrm{CP} 2$ and chilli interaction.

\section{MATERIALS AND METHODS}

\subsection{Microorganism}

Colletotrichumtruncatum $\mathrm{CP} 2$ was used in this study. The fungal isolate was isolated from lesions of chilli fruit. The pure culture was transferred to PDA slants and maintained at $4{ }^{\circ} \mathrm{C}$. C. gloeosporiodes was used as a reference (Heng et al., 2011).

\subsection{Medium composition for enzyme production}

In this study, basal medium was used as the medium for the production of cellulases and pectinases under submerged fermentation. Composition of basal medium used was as follow (g/L): (NH4)2SO4, 1.4; $\mathrm{K}_{2} \mathrm{HPO}_{4}, 6.0 ; \mathrm{KH}_{2} \mathrm{PO}_{4}, 2.0$; $\mathrm{MgSO}_{4} \cdot 7 \mathrm{H}_{2} \mathrm{O}, 0.1$ and carbon source (pectin or carboxymethyl cellulose), 10. 


\subsection{Production of cellulases and pectinases by $C$. truncatum CP2 in submerged fermentation}

Enzyme production was carried out under submerged fermentation. The basal media (pH 5.0) were inoculated with $8 \mathrm{~mm}$ diameter culture discs of the fungal isolate. The cultures were harvested after incubation at $30^{\circ} \mathrm{C}$ for $2,4,6,8,10$ and 12 days and centrifuged at 10,000 rpm for 20 min before determining the enzyme activity.

\subsection{Pectinolytic enzymes assays}

Polygalacturonase (PG) activity, the method of Nelson and Somogyi (Nelson, 1944) was used to measure the release of reducing groups from polygalacturonic acid. The reaction mixture contained $1.8 \mathrm{~mL}$ of $1 \%$ PGA in $50 \mathrm{mM}$ sodium acetate buffer ( $\mathrm{pH} 4.8$ ) and $0.2 \mathrm{~mL}$ of crude enzyme. The boiled enzyme served as a control. The reaction mixture was then incubated at $40^{\circ} \mathrm{C}$ for $30 \mathrm{~min}$ followed by addition of $3 \mathrm{~mL}$ of 3,5-dinitrosalicyclic (DNS) reagent. Reaction was stopped by heating the reaction mixture at $100{ }^{\circ} \mathrm{C}$ for $15 \mathrm{~min}$. Then, the tube was cooled at room temperature before adding $1 \mathrm{~mL}$ of Rochelle salt. The absorbance was read at $545 \mathrm{~nm}$ using a spectrophotometer. The amount of reducing sugars was calculated using D-galacturonic acid as a standard. The amount of enzyme releasing $1 \mu \mathrm{mol}$ of galacturonic acid per min at $\mathrm{pH} 4.8$ and $40^{\circ} \mathrm{C}$ was considered as one enzyme unit.

Pectin methylesterase (PME) activity was determined by the method of Hagerman and Austin (1986). Samples of crude enzymes $(0.1 \mathrm{~mL})$ was added to a reaction mixture contained the following: $1.0 \mathrm{~mL}$ pectin solution $(0.01 \%), 0.2 \mathrm{~mL} \mathrm{NaCl}$ $(0.05 \mathrm{M}), 0.1 \mathrm{~mL}$ bromothymol blue solution and $0.2 \mathrm{~mL}$ distilled water in a cuvette. After that, the cuvette was shaken gently and the absorbance was immediately measured at $620 \mathrm{~nm}$ using a spectrophotometer. After $3 \mathrm{~min}$, the absorbance was measured again. The difference in the absorbance was measured as the PME activity. The activity of the PME was calculated using D-galacturonic acid standard curve.

Pectinlyase (PL) and pectate lyase (PNL) activities were assayed by the thiobarbituric acid method (Olutiola and Akintunde, 1979). Samples $(0.2 \mathrm{~mL})$ of culture filtrates were added to $1.8 \mathrm{~mL}$ of $1.0 \%$ pectin dissolved in $0.05 \mathrm{M}$ sodium citrate buffer $\mathrm{pH} 4.8$ and the mixtures were incubated for at $40^{\circ} \mathrm{C}$ for $30 \mathrm{~min}$. The reactions were stopped by the addition of $1.5 \mathrm{~mL}$ of $1 \mathrm{~N}$ $\mathrm{HCl}$ and $3 \mathrm{~mL}$ of $0.04 \mathrm{M}$ thiobarbituric acid into the reaction mixtures. The reactions were kept at $100{ }^{\circ} \mathrm{C}$ for $15 \mathrm{~min}$ and the absorbance was read at $550 \mathrm{~nm}$ afterwards. One unit of lyase activity was defined as the amount of enzyme causing an absorbance change of 0.01 under the described conditions.

\subsection{Cellulases enzyme assay}

Filter paperase (FPase) was determined by measuring the released of reducing sugar from the filter paper. The crude enzyme $(0.2 \mathrm{~mL}$ ) was mixed with $1 \times 6 \mathrm{~cm}$ (Whatman No. 1) filter paper strip $(3 \times 1 \mathrm{~cm})$ and immersed in $1.8 \mathrm{~mL}$ of $50 \mathrm{mM}$ sodium citrate buffer $(\mathrm{pH} 4.8)$. It was then incubated at $40{ }^{\circ} \mathrm{C}$ for 1 hour. The absorbance was measured at $575 \mathrm{~nm}$ using spectrophotometer. Activity of FPase was determined by DNS method (Miller, 1959) against standard curve of glucose. One unit of enzyme activity was defined as the amount of enzyme required to liberate $1 \mu$ mole of reducing sugar per minute under standard assay conditions.

\subsection{Protein assay}

Protein concentration in the culture filtrates was estimated by Bradford method (Bradford, 1976). Protein content was determined by adding $100 \mu \mathrm{L}$ of sample to $3.0 \mathrm{~mL}$ of Bradford reagent. Absorbance was measured at $595 \mathrm{~nm}$ using UV visible spectrophotometer. Protein concentration in the unknown samples were calculated from standard curve of Bovine Serum Albumin and expressed as $\mathrm{mg}$ protein per $\mathrm{mL}$. As for the blank, $1 \mathrm{~mL}$ of sample solution was replaced with $1 \mathrm{~mL}$ distilled water.

\subsection{Mycelium dry weight}

Pre-weighed Whatman No. 1 filter paper was used to filter mycelium. Dry weight of mycelium was measured after drying to a constant weight at $80^{\circ} \mathrm{C}$. The dry weight of mycelium was calculated based on equation below:

$$
\text { Dry cell weight }=\frac{(\text { Dried filter paper }+ \text { mycelium })-(\text { dried filter paper })(g)}{\text { volume of the cell }(m L)}
$$

\section{RESULTS AND DISCUSSION}

In the present study, pectinolytic and cellulolytic enzymes production by $C$. truncatum $\mathrm{CP} 2$ was characterized in synthetic medium containing pectin as carbon source with the C. gloeosporiodes served as a control. Fig.1 to Fig.5 shows the growth 
and pectinolytic enzyme production by both pathogens. Based on the results of the present study, both of the pathogens were able to grow in the medium containing pectin and produced pectinolytic enzymes. In general, higher pectinolytic enzymes (PG, PME, PL and PNL) and mycelium growth were produced by $C$. truncatum $\mathrm{CP} 2$ compared to $C$.

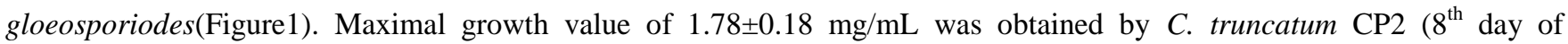
fermentation) which was about 2-fold higher than obtained by $C$. gloeosporiodes.

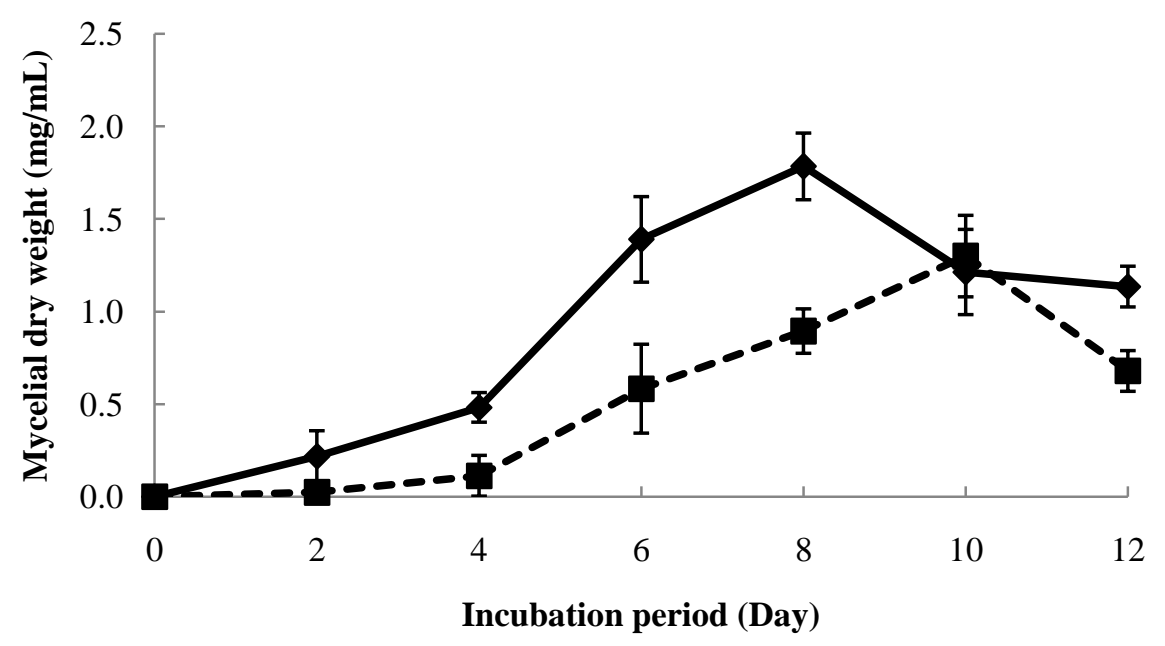

\section{FIGURE 1: GROWTH PATTERNS OF C. TRUNCATUM CP2 (») AND C. GLOEOSPORIODES (ロ) IN MEDIUM CONTAINING PECTIN FROM CITRUS AS A CARBON SOURCE. VALUES ARE MEANS OF 3 REPLICATES WITH \pm SD.}

Higher production of PG enzyme was produced by $C$. truncatum $\mathrm{CP} 2$ after $6^{\text {th }}$ day of fermentation $(0.24 \pm 0.10 \mathrm{U} / \mathrm{mL}) \mathrm{which}$ was earlier compared to other enzymes. The PG activity trend was similar to that $C$. gloeosporiodes cultivated in the medium containing pectin from citrus as carbon source (Figure 2). The activity of PME was almost constant throughout the infection process except a slight increase at day 8, which suggested that the PME plays a little role after formation of pectic substances (Figure 3). Data on PL (Figure4) and PNL (Figure5) of $C$. truncatum CP2 revealed that these enzymes increased throughout the infection process and reached their highest level following the day of maximum growth in which $1.80 \pm 0.12 \mathrm{U} / \mathrm{mL}$ and $32.7 \pm 1.23 \mathrm{U} / \mathrm{mL}$ were obtained after $8^{\text {th }}$ day of fermentation, respectively. In comparison, C. truncatum $\mathrm{CP} 2$ shows higher production of PME, PL and PNL than C. gloeosporiodes.

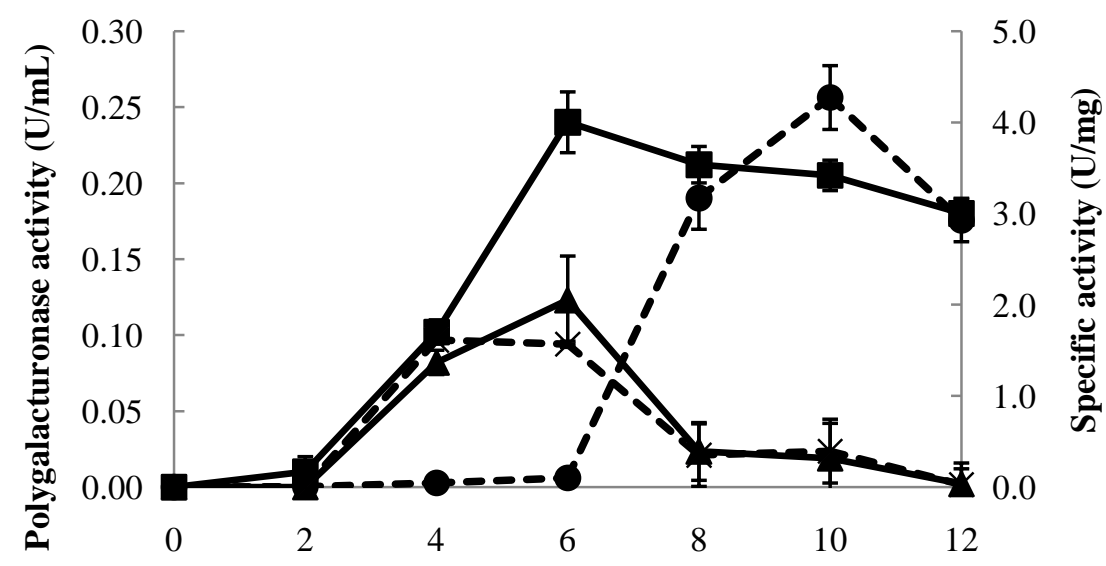

Days of incubation

Figure 2: Production of PG by C. truncatum CP2 (a) And C. gloeosporiodes (A) USING PeCTiN FROM CITRUS AS A CARBON SOURCE. VALUES ARE MEANS OF THREE REPLICATES \pm SD. SYMBOLS REPRESENT (•) SPECIFIC ACTIVITY FOR C. TRUNCATUM CP2 AND ( $\times$ ) SPECIFIC ACTIVITY FOR $C$. GLOEOSPORIODES. 


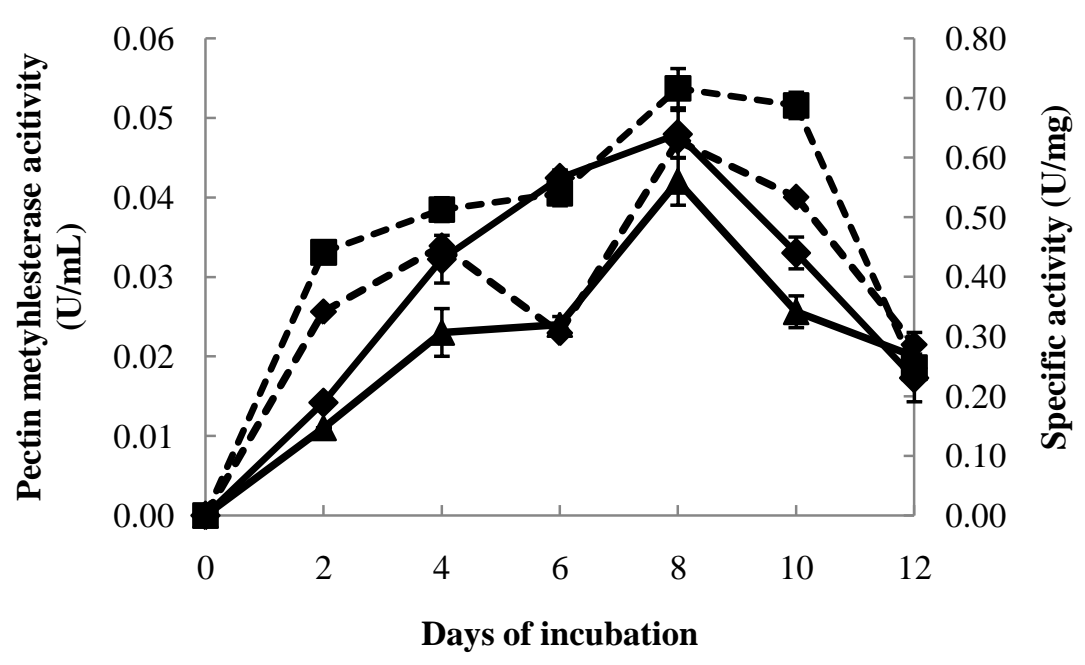

Figure 3: Production of PME by C. TRUNCATUM CP2 ( $\diamond$ AND C. GLOEOSPORIODES ( $\triangle$ ) USING PECTIN FROM CITRUS AS A CARBON SOURCE. VALUES ARE MEANS OF THREE REPLICATES \pm SD. SYMBOLS REPRESENT ( $\bullet$ ) SPECIFIC ACTIVITY FOR C. TRUNCATUM CP2 AND (ロ) SPECIFIC ACTIVITY FOR C. GLOEOSPORIODES.

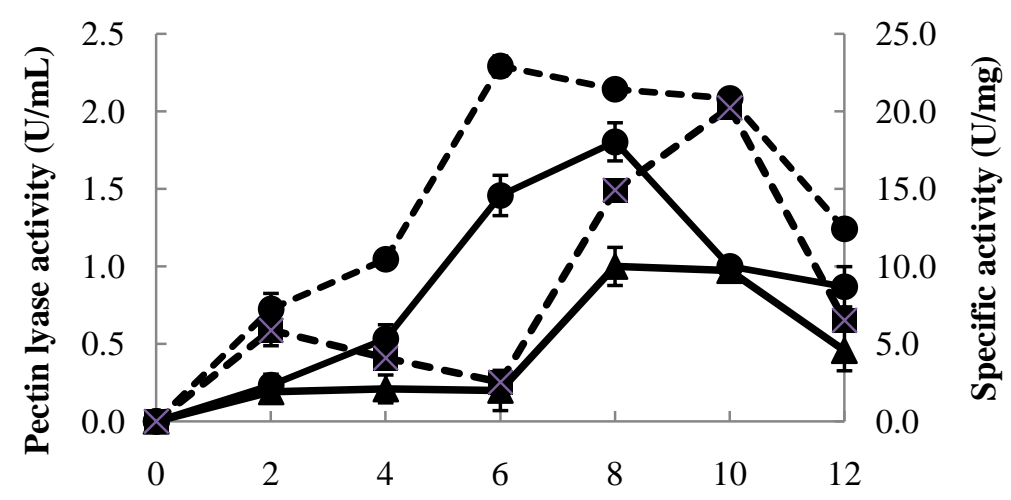

Fermentation time (Day)

Figure 4: Production of PL by C. TRUNCATUM CP2 (•) AND C. GLOEOSPORIODES ( $\triangle$ ) USING PECTIN FROM CITRUS AS A CARBON SOURCE. VALUES ARE MEANS OF THREE REPLICATES \pm SD. SYMBOLS REPRESENT ( $($ ) SPECIFIC ACTIVITY FOR C. TRUNCATUM CP2 AND ( $\times$ ) SPECIFIC ACTIVITY FOR C. GLOEOSPORIODES.

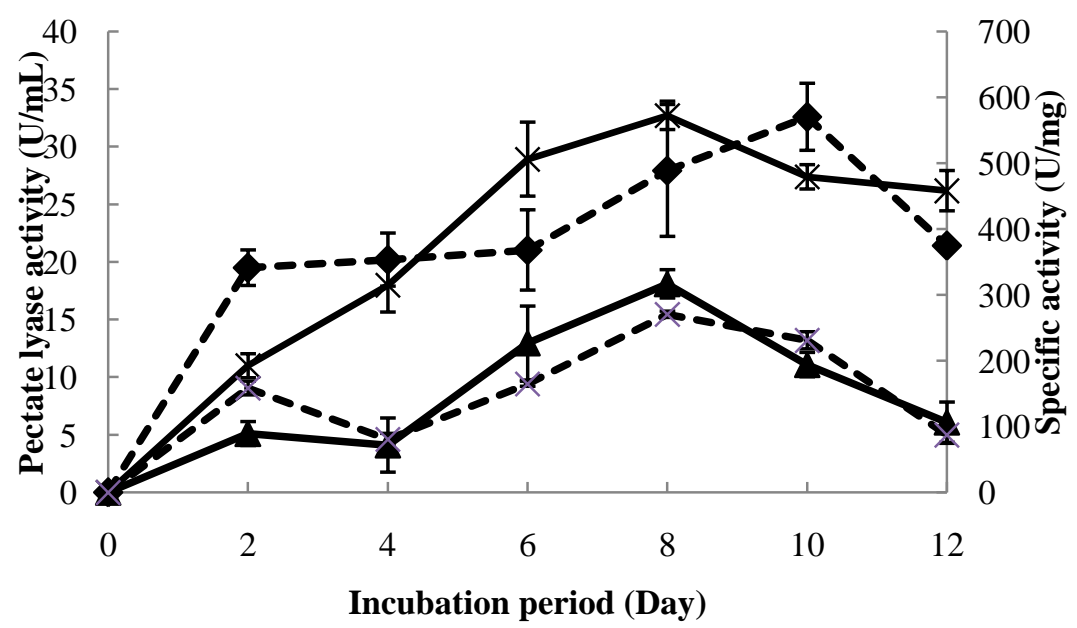

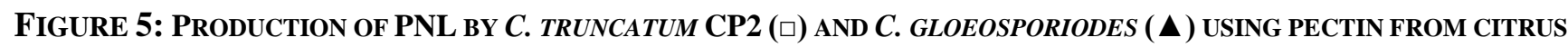
AS A CARBON SOURCE. VALUES ARE MEANS OF THREE REPLICATES \pm SD. SYMBOLS REPRESENT ( $\downarrow$ ) SPECIFIC ACTIVITY FOR C. TRUNCATUM CP2 AND ( $\times$ ) SPECIFIC ACTIVITY FOR C. GLOEOSPORIODES. 
The ability of $C$. truncatum $\mathrm{CP} 2$ and $C$. gloeosporiodes to produce cellulases enzymes was investigated in this study. Both of these fungal pathogens were able to grow in the media containing CMC as a carbon source. However, the production of cellulase by $C$. truncatum $\mathrm{CP} 2$ was much lower than $C$. gloeosporiodes (Fig.6). FPase activity detected from $C$. truncatum $\mathrm{CP} 2$ was about $1.85 \pm 0.21 \mathrm{U} / \mathrm{mL}$ while maximum FPase activity was observed in $C$. gloeosporiodes was $2.19 \pm 0.40 \mathrm{U} / \mathrm{mL}$.

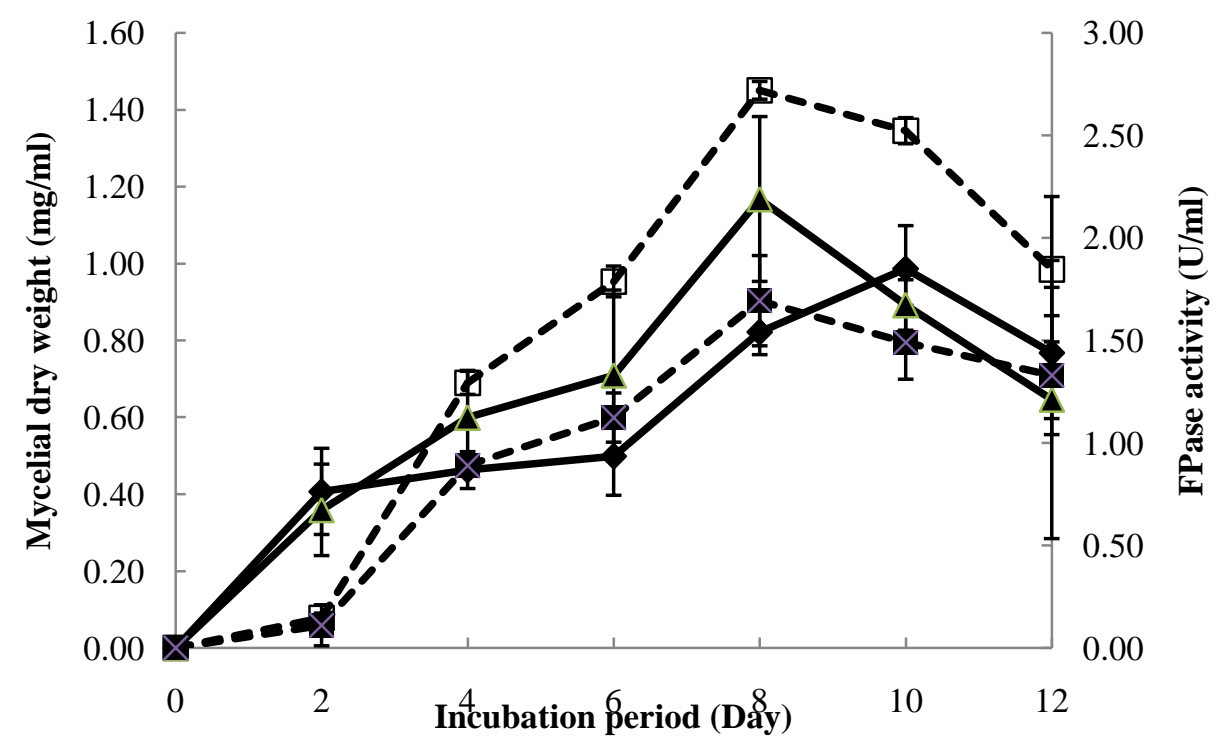

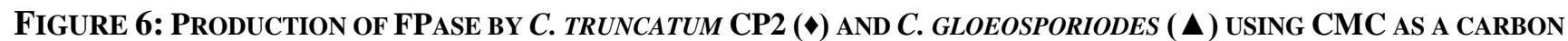
SOURCE. VALUES ARE MEANS OF THREE REPLICATES \pm SD. SYMBOLS REPRESENT ( $($ ) SPECIFIC ACTIVITY FOR $C$. TRUNCATUM CP2 AND (O) SPECIFIC ACTIVITY FOR C. GLOEOSPORIODES.

The plant cell wall is a major barrier to the establishment of fungal infection on a host. Most plant-pathogenic fungi produce a number of cell wall-degrading enzymes when grown in liquid culture containing pectin. One of these enzymes, PG has been implicated routinely in facilitating the invasion and colonization of host tissue during pathogenesis of fungal pathogens (Choi et al., 2013). The results of the present study demonstrated that both of the Colletotrichum species have the ability to produce pectinolytic and cellulolytic enzymes. The early secretion of PG by C. truncatum CP2 allows the breakdown of pectic substances. For most necrotrophic fungi, large amounts of pectinolytic enzymes are typically secreted first because it is the only cell wall-degrading enzymes capable of macerating plant tissues and killing plant cells (D'Ovidio et al. 2004). PG activity obtained in this work is comparable with other phytopathogenic fungi when using pectin as a carbon source. Earlier, Fernandezet al.(1993)reported maximum PG activity of $0.4 \mathrm{U} / \mathrm{mLby}$ Fusarium oxysporum when grow in pectin whereas about $0.24 \mathrm{U} / \mathrm{mL}$ of PG activity was produced by C. lindemuthianum was reported by Hugouvieuxet al. (1997).

The difference observed in the production of pectinolytic enzymes (PG, PME, PL and PNL) activities can be related to the specific role of these enzymes during pathogenesis. The earlier secretion of PG indicates that this enzyme is the most important pectinolytic enzymes that initiates the process of cell wall degradation and facilitates penetration of the pathogen into the host tissues. This result is in close agreement with Oeseret al. (2002) who reported that endoPG is the pathogenicity factor in the Clavisepspurpurea/rye interaction. In contrast, higher PL and PNL activities appear later which correlated with the necrotrophic phase of tissue colonization. The sequential secretion of these cell wall-degrading enzymes indicates that the pectinolytic enzymes are required to enhance the accessibility of cell wall components for degradation by other enzymes such as cellulases. The contribution of PG, PME and PL to the pathogenicity of some fungal pathogenshas been studied by gene disruption or replacement experiments. For example, the pelB mutant of C. gloeosporiodes had shown 36-45\% reduction in rotting diameter of avocado compared to the wild type isolate which indicate the important role of PL on the pathogenicity of $C$. gloeosporiodes on avocado fruits (Yakoby et al., 2001). Valette-Collet et al. (2003) reported that pathogenicity tests of a Bcpmel disrupted mutant obtained from Botyriscinerea on Arabidopsis thaliana and apple fruit showed reduction in rotting activities compared to the wild-type strain, which suggested that PME enzyme play a major role in pathogenesis of $B$. cinerea.

Cellulose is a major polysaccharides present in the plant cell wall and microorganism therefore require specific enzymes for the degradation of cell wall. A number of plant-pathogenic fungi produced cellulolytic enzymes capable of hydrolysing cellulose and its derivatives (Laine et al., 2000; Wanjiru et al., 2002). The results obtained in the present study indicate that 
pathogens $C$. truncatum strain CP2 produced cellulolytic enzymes which able to degrade CMC and the activity increased in age of the culture. The involvement of cellulases in pathogenicity of plant-pathogenic fungi has been demonstrated in previous studies (Babalola, 2010). Eshel et al. (2002) reported on secretion of endocellulase by Alternariaalternata which directly influenced the disease development in persimmon fruit.

In this study, the pectinolytic and cellulolytic enzymes activity detected in vitro indicate the involvement of these enzymes in development of disease by $C$. truncatum $\mathrm{CP} 2$ in chilli fruits. The secretion of pectinolytic and cellulolytic enzymes give ability for this phytopathogenic fungus to invade host tissues which differ in their polysaccharide cell wall composition (Bellincampi et al., 2014). Many previous studies have reported on fungal pathogens such as $C$. capsici which secrete both cellulolytic and pectinolytic enzymes to invade the host plant cell walls (Anand et al.2008). Similar results were also reported by (Acosta-Rodríguez et al., 2005).

\section{CONCLUSION}

In conclusion, cellwall-degrading enzymes likely to be involved in cellwall degradation during surface host penetration and invasion are both pectinases and cellulose. PG was the most important enzyme in initiating the process of cellwall degradation. Once the cellwall was degraded by the action of PG, further degradation of the cellwall was influenced by PME, PL, PNL and cellulases. The variation in enzymatic activity at different intervals may suggest their specific role for pathogenesis at proper timings.

\section{ACKNOWLEDGEMENTS}

The authors would like to thank the Ministry of Higher Education Malaysia (Grant No. FRGS/2//2013/SG05/UPM/02/21) for financial support.

\section{REFERENCES}

[1] Acosta-Rodríguez, I., Piñón-Escobedo, C., Zavala-Páramo, M. G., López-Romero, E., \& Cano-Camacho, H. (2005).Degradation of cellulose by the bean-pathogenic fungus Colletotrichumlindemuthianum.Production of extracellular cellulolytic enzymes by cellulose induction. Antonie Van Leeuwenhoek, 87(4), 301-310.

[2] Anand, T., Bhaskaran, R., Gandhi Karthikeyan, T., Rajesh, M., \&Senthilraja, G. (2008).Production of cell wall degrading enzymes and toxins by Colletotrichumcapsici and Alternariaalternata causing fruit rot of chillies. Journal of plant protection research, 48(4), 437-451.

[3] Babalola, O. O. (2011). Pectinolytic and cellulolytic enzymes enhance Fusarium compactum virulence on tubercles infection of Egyptian broomrape. International journal of microbiology, 2010.

[4] Bellincampi, D., Cervone, F., \&Lionetti, V. (2014).Plant cell wall dynamics and wall-related susceptibility in plant-pathogen interactions. Frontiers in plant science, 5.

[5] Choi, J., Kim, K. T., Jeon, J., \& Lee, Y. H. (2013). Fungal plant cell wall-degrading enzyme database: a platform for comparative and evolutionary genomics in fungi and Oomycetes. BMC genomics, 14(5), S7.

[6] D'Ovidio, R., Mattei, B., Roberti, S., \&Bellincampi, D. (2004).Polygalacturonases, polygalacturonase-inhibiting proteins and pectic oligomers in plant-pathogen interactions. BiochimicaetBiophysicaActa (BBA)-Proteins and Proteomics, 1696(2), 237-244.

[7] Eshel, D., Miyara, I., Ailing, T., Dinoor, A., \&Prusky, D. (2002).pH regulates endoglucanase expression and virulence of Alternariaalternata in persimmon fruit. Molecular plant-microbe interactions, 15(8), 774-779.

[8] Laine, M. J., Haapalainen, M., Wahlroos, T., Kankare, K., Nissinen, R., Kassuwi, S., \& Metzler, M. C. (2000). The cellulase encoded by the native plasmid of Clavibactermichiganensis ssp. sepedonicus plays a role in virulence and contains an expansin-like domain. Physiological and Molecular Plant Pathology, 57(5), 221-233.

[9] Leone, G. (1992). Significance of polygalacturonase production by Botrytis cinereain pathogenesis. Recent advances inBotrytisresearch, 63.

[10] Niture, S. (2008).Comparative biochemical and structural characterizations of fungal polygalacturonases. Biologia, 63(1), 1-19.

[11] Rogers, L. M., Kim, Y. K., Guo, W., González-Candelas, L., Li, D., \&Kolattukudy, P. E. (2000). Requirement for either a host-or pectin-induced pectate lyase for infection of Pisumsativum by Nectriahematococca. Proceedings of the National Academy of Sciences, 97(17), 9813-9818.

[12] Saxena, A., Raghuwanshi, R., Gupta, V. K., \& Singh, H. B. (2016). Chilli anthracnose: The epidemiology and management. Frontiers in microbiology, 7.

[13] Valette-Collet, O., Cimerman, A., Reignault, P., Levis, C., \&Boccara, M. (2003). Disruption of Botrytis cinerea pectin methylesterase gene Bcpme1 reduces virulence on several host plants. Molecular Plant-Microbe Interactions, 16(4), 360-367.

[14] Wanjiru, W. M., Zhensheng, K., \&Buchenauer, H. (2002).Importance of cell wall degrading enzymes produced by Fusarium graminearum during infection of wheat heads. European Journal of Plant Pathology, 108(8), 803-810.

[15] Yakoby, N., Beno-Moualem, D., Keen, N. T., Dinoor, A., Pines, O., \&Prusky, D. (2001).ColletotrichumgloeosporioidespelB is an important virulence factor in avocado fruit-fungus interaction. Molecular Plant-Microbe Interactions, 14(8), 988-995. 